\title{
Kidney Oncocytoma
}

National Cancer Institute

\section{Source}

National Cancer Institute. Kidney Oncocytoma. NCI Thesaurus. Code C4526.

A benign tumor of the kidney, characterized by the presence of large cells with abundant eosinophilic granular cytoplasm. The majority of these tumors are discovered incidentally, during work-up of other conditions. 